\title{
Staff Experiences of Victoria University's First Year College During the Implementation of Block Mode Teaching
}

\author{
Humberto Oraison, Loretta Konjarski, Janet Young, Samuel Howe, Andrew \\ Smallridge
}

First Year Collge, Victoria University, Australia.

\begin{abstract}
This report reviews the findings of staff satisfaction surveys conducted in 2018 and 2019 following the creation of a transformative and revolutionary approach to tertiary education in Australia, namely the creation of a new First Year College at Victoria University. Lectures were abolished from all units; class sizes were reduced; class timetabling was dramatically changed to allow for greater student study flexibility and accessibility; learning and teaching professional staff numbers were increased and facilities were built and repurposed. This report discusses the staff satisfaction and challenges encountered by staff in 2018 and 2019 providing quantitative and qualitative data. This data revealed high levels of satisfaction along with concerns about workload and related issues. Variations between 2018 and 2019 indicate that despite an increase in overall satisfaction, staff were concerned about awards and recognition, involvement in decisions that affected them, and receiving support to conduct their roles. The First Year College implemented a series of measures to address the issues raised in the 2018 survey. Further measures are recommended following the 2019 survey as well as future surveys that include stress levels and other psychological markers.
\end{abstract}

Keywords: Staff Satisfaction; Tertiary Education; Academic Transformation; Staff Challenges. 


\section{Introduction}

In 2018 Victoria University (VU) embarked upon a transformative and innovative approach to delivering tertiary education in Australia (Victoria University, 2017). VU set about developing and implementing the VU First Year Model (FYM), and this was supported by the creation of a First Year College (FYC). During 2018, the FYC delivered 160 units using block mode (intensive, one unit at a time condensed form of teaching), supported by studentcentered learning and three highly engaging three-hour workshops per week. The workshops were based in active learning principles (Kift, 2015) and replaced the traditional lecture/tutorial delivery. All assessment and feedback is completed during the four-week block. Each unit was underpinned by transitions pedagogies (Kift, \& Field 2009; Kift, 2015).

The success of the First Year Model (FYM) has led to its further implementation across all years of undergraduate courses at VU, beginning with second year courses in 2019. FYC staff from all disciplines supported and collaborated with each other in the planning of units, assessments and student-centered engagement activities (McCluskey, Weldon, \& Smallridge, 2018). As the staff survey results indicate, there was a sense of belonging and collegiality that was deemed important to most staff.

Research on university staff has found consistent levels of distress amongs academics. A Malaysian study measured six dimensions of satisfaction on university teaching staff: leadership, staff involvement, workload, self-development, working environment and communication. Findings indicated a moderate level of satisfaction (Sidik, Ab Hamid, \& Ibrahim, 2017). University staff may suffer from high levels of anxiety, depression, and stress related illness compared to general population samples (Winefield, \& Jarrett, 2001; Mark, \& Smith, 2012). Winefield, Gillespie, Stough, Dua, Hapuarachchi, and Boyd (2003) found that work overload, time pressure, lack of prospects, poor levels of reward and recognition, fluctuating roles, poor management, poor resources and funding, and student interactions, expectations, low job security, lack of communication, inequality, and lack of feedback were associated with stress in universities in the UK. Winefield and Jarret (2001) reported that $43.7 \%$ of university staff had high levels of anxiety and depression in a sample of over 2000 Australian university employees. In addition, these authors found strong associations between efforts, demands, control, supports, and rewards, and depression, anxiety, and job satisfaction and also between coping and attributional style. Rewards, social support, job control, and positive coping and attributional behaviours were associated with lower levels of depression and anxiety and high job satisfaction it was also found that university staff were more likely to claim that workplace conditions had caused or made an illness worse and were twice as likely to complain of stress or anxiety and depression-related illness (Winefield \& Jarret). 
Mark and Smith (2010) found strong associations between the traditional variables of efforts, demands, control, supports, and rewards, and depression, anxiety, and job satisfaction and also between coping and attributional style and these outcomes. In a 2003 study university staff reported concerns with excessive workloads, unbalanced rewards systems and lack of support. However, staff appeared to be satisfied overall and willing to continue working for the university (Houston, Meyer, \& Paewai, 2006).

\section{Methods}

\subsection{Participants}

In March 2018 and 2019, First Year College staff were surveyed about their experiences in the newly implemented First Year College (FYC). The staff of the FYC consist of 76\% fulltime and $24 \%$ part-time academics. Academic teaching researchers (ATRs, research and teaching focussed) make up $45 \%$ of this cohort , academic teaching scholars (ATSs, teaching focussed) the other 55\%. There was a 30\% participation rate in 2018 and $29 \%$ in 2019 from total of a 106 staff members.

\subsection{Materials}

The First Year College devised a survey that sought to identify what had worked well for teaching staff, together with the key challenges faced in delivering the revolutionary FYM. The survey consisted of 18 questions including three open-ended questions that allowed staff to respond in their own words about their work environment, successes and challenges. There were two demographic questions; "What is your role? and What is your enrolment status?" and 13 quantitative questions to answer on a Likert 4-point scale from strongly disagree (0) to strongly agree (4) (see table 1).

\subsection{Procedure}

Every ongoing (full \& part-time) member of staff was contacted by email by the Dean and invited to participate in the survey via a link. Staff were advised of the voluntary and confidential nature of the survey as well as the approximate time it would take to complete (20 minutes). The Human Resources department at VU were responsible for the collection and collation of the data and the reporting of this to the FYC Dean. A general overview of de-identified results was reported to the FYC leadership group. Researchers obtained a full copy and transcript of the findings of the two surveys following a request to the Dean of the FYC. 


\section{Results}

Quantitative Responses Staff responses to a set of 13 questions about the FYC and work environment are listed in Table 1.

Table 1. Staff Responses Relating to the FYC and Work Environment Comparison between 2018 and 2019.

\begin{tabular}{|c|c|c|c|}
\hline Agree - Strongly Agree Answer & 2018 & 2019 & Variation \\
\hline I am proud to tell people where I work & 86.21 & 91.49 & 5.28 \\
\hline $\begin{array}{l}\text { The FYC motivates me to go above and beyond in } \\
\text { my role }\end{array}$ & 86.21 & 85.10 & -1.11 \\
\hline $\begin{array}{l}\text { I can see myself working in the FYC in } 2 \text { years' } \\
\text { time }\end{array}$ & 82.76 & 89.36 & 6.60 \\
\hline I am very satisfied with my current job & 72.41 & 87.23 & 14.82 \\
\hline I have confidence in the FYC leadership team & 93.10 & 87.23 & 5.87 \\
\hline I know what is expected of me at work & 93.10 & 91.70 & -2.40 \\
\hline $\begin{array}{l}\text { I have the materials and equipment I need to do my } \\
\text { work right }\end{array}$ & 93.10 & 87.24 & -8.86 \\
\hline $\begin{array}{l}\text { I find my day to day work challenging and } \\
\text { interesting }\end{array}$ & 100 & 91.49 & -8.51 \\
\hline $\begin{array}{l}\text { In the last ten days, I have received recognition or } \\
\text { praise for doing good work }\end{array}$ & 96.20 & 65.95 & -26.25 \\
\hline $\begin{array}{l}\text { I am given the opportunity to be involved in } \\
\text { decisions that affect me }\end{array}$ & 82.76 & 65.95 & -16.81 \\
\hline At work, all my colleagues are treated with respect & 96.35 & 87.23 & -9.12 \\
\hline $\begin{array}{l}\text { I feel that I have the necessary support I need to } \\
\text { perform successfully in my role }\end{array}$ & 88.89 & 82.22 & -6.61 \\
\hline I feel I am coping with the new block model & 86.21 & 84.45 & -1.76 \\
\hline
\end{tabular}

Table 1 shows positive and negative variation with a particularly large negative variation in relation to recognition and praise. However, there was a marked increase in job satisfaction levels.

In an inductive content analysis process recommended by Nowell et al. (207) three open questions were formulated. Firstly, provide "General comments about the environment". Key themes identified were high satisfaction levels, elevated motivation and good opportunities 
for personal growth which were consistent across both years. Secondly, staff were asked "What Worked Well for Teaching Staff within their Immediate Work Area?" and identified "team work and collegiality", "student focused approach" and " critical support for teachers" as strength and positive elements consistently over 2018 and 2019. Finally, in relation to the question: " Tell us about some things that could be changed or improved." there was a bigger range of themes and noticeable differences between both years. One of the main themes was: "Review excessive workloads" which appear to be a bigger concern in 2019 with a large of comments regarding this issue. There were further comments related to class and room allocations, office spaces, breaks between classes, breaks between blocks and other challenges for academics.

\section{Discusssion}

Results indicated that the primary challenge for all staff were related to increases in workload, with longer teaching hours, faster turnarounds required for marking and continual updating of the learning management system online spaces compared to "traditional" university teaching. Using these principles in conjunction with developing engaging three-hour workshops was certainly a challenge and many staff worked on unit development until day one of the semester. It was a time of great innovation in the areas of pedagogy, engagement and assessment. While many Australian academics and institutions support the concepts and philosophy of transitional pedagogy, only VU has adopted institution-wide reforms and transformation in this area (Victoria University's Transformational Agenda, 2017). A strategic whole of institution suite of transition activities including curricular, co-curricular and administrative support functions are mediated through "the organizing device of curriculum" (Kift, \& Nelson, 2005, p. 232). The results are consistent with those of Kiplangat, Momanyi and Kangethe (2017) as high level of staff satisfaction were reported despite concerns about workloads and other class allocations. The high level of approval of managerial leadership practices may influence satisfaction levels. The staff responses revealed high scores for leadership, staff involvement and working environmentand communication leading to higher levels of satisfaction and desire to continue to work at the FYC (Sidik, Hamid, \& Ibrahim, 2017).

There were many successes in the implementation of the FYC and the FYM, there were also many challenges. Major organisational change operates at many levels including process, structures, systems and institution wide obstacles (Marshall, 2012). While the primary focus of the FYC and the FYM was to make the curriculum student-centered and engaging, the shift to block mode-teaching delivery had wide reaching effects. VU's Transformation Change paper (Victoria University, November 2017), as part of the organisational and revolutionary transformation recommended the implementation a First Year College, a separate entity that has dramatically changed (revolutionized) tertiary education with a 
complete overhaul of the teaching strategies and content delivery. In addition, themes and concerns are consistent with previous literature in relation to poor levels of reward and recognition, work overload and time pressure which may cause stress and anxiety amongst staff (Mark, \& Smith, 2010; Winefiled, \& Jarred, 2001: Winefield et al., 2003). The results also indicated that social support may also influence levels of satisfaction (Mark, \& Smith, 2010).

Despite this, the results from the FYC Survey are most encouraging. They suggest the teaching staff have, in the main, embraced, endorsed and appreciated their involvement in the block-teaching model. Results indicated an increase in overall staff satisfaction, staff confidence in the leadership and very high likehood that staff would be working for the FYC in the two years. The quantitative and qualitative results appear to be consistent and congruent indicating a desire for recognition and inclusion in decision making as well as a need for technical support. However, the generasibility of the findings appears limited given a relatively low participation rates. A follow-up survey in 2020 may be useful to monitor the reaction to changes implemented as results of this research and may include measures of stress and ability to cope.

In response to the surveys conducted so far a number of initiatives have been implemented to minimize staff burn-out. These include: A FYC Wellness committee, Women in First Year College group, review of roles and responsibilities of ATS and ATR staff, review of workload allocation across the year, access to professional development to support teaching staff and one-on-one meetings with the Dean for each teaching staff member. Improvements and enhancement in staff satisfaction levels as a result of the surveys validate these instruments as efficient evaluation tools.

\section{References}

Houston, D., Meyer, L. H., \& Paewai, S. (2006). Academic Staff Workloads and Job Satisfaction: Expectations and Values in Academe. Journal of Higher Education Policy and Management, 28(1), 17-30. Retrieved from https://search-ebscohostcom.wallaby.vu.edu.au:4433/login.aspx?direct=true $\& d b=$ eric $\& A N=E J 729118 \&$ site $=e d$ s-live

Kift, S. (2015). A decade of Transition Pedagogy: A quantum leap in conceptualising the first year experience. HERDSA Review of Higher Education, 2, 51-86.

Kift, S. M., \& Field, R. M. (2009). Intentional first year curriculum design as a means of facilitating student engagement: some exemplars. In Proceedings of the 12th Pacific Rim First Year in Higher Education Conference. Queensland University of Technology.

Kift, S., Nelson, K. \& Clarke, J. (2010). Transition Pedagogy: A third generation approach to FYE - A case study of policy and practice for the higher education sector. The International Journal of the First Year in Higher Education, 1(1), 1-20. 
Kiplangat, H. K., Momanyi, M., \& Kangethe, N. S. (2017). Dimensions of Kenyan University Academic Staff's Job Satisfaction in View of Various Managerial Leadership Practices. Journal of Education and Practice, 8(3), 120-129.

Lizzio, A., \& Wilson, K. (2004). First-year students' perceptions of capability. Studies in Higher Education, 29(1), 109-128.

Mark, G., \& Smith, A. (2012). Effects of occupational stress, job characteristics, coping, and attributional style on the mental health and job satisfaction of university employees. Anxiety, Stress \& Coping, 25(1), 63-78. https://doiorg.wallaby.vu.edu.au:4433/10.1080/10615806.2010.548088

Marshall, S.(2012). E-learning and higher education: Understanding and supporting organisational change. New Zealand. Journal of Open, Flexible, and Distance Learning, 16(1), 141-155.

McCluskey, T., Weldon, J \& Smallridge, A. (2018) Rebooting the First Year ExperienceHigher Education. HERDSA (RE)Valuing Higher Education 2018 Conference.

Retrievedfrom:http://herdsa2018.aomevents.com.au/wpcontent/uploads/sites/25/2018/0 7/HERDSA-Abstract_Book-2018-opt.pdf

McCluskey, T., Weldon, J \& Smallridge, A. (2018) Rebuilding the First Year ExperienceOne Block at a Time. STARS 2018 Conference (p. 174), Retrieved from: https://unistars.org/proceedings/

Nowell, L. S., Norris, J. M., White, D. E., \& Moules, N. J. (2017). Thematic Analysis: Striving to Meet the Trustworthiness Criteria. International Journal of Qualitative Methods, 16(1),1.https://doi.org.wallaby.vu.edu.au:4433/10.1177/1609406917733847

O’Donnell, M., Wallace, M., Melano, A., Lawson, R., \& Leinonen, E. (2015). Putting transition at the centre of whole-of-curriculum transformation. Student Success, 6(2), 7379.

Sidik, M., Ab Hamid, M. R., \& Ibrahim, A. (2017). Descriptive Analysis of Staff Satisfaction and Turnover Intention in a Malaysian University. AIP Conference Proceedings, 1842(1), 1-13. https://doi-org.wallaby.vu.edu.au:4433/10.1063/1.4982874

Victoria University's Transformational Agenda (2017). A white paper on the future of Victoria University. Available from: https://www.vu.edu.au/sites/default/files/whitepaper-vu.pdf.

Winefield, A. H., Gillespie, N., Stough, C., \& Dua, J. Hapuarachchi, J., Boyd, C.(2003.). Occupational Stress in Australian University Staff: Results From a National Survey. International Journal of Stress Management, 10(1), 51-63. https://doiorg.wallaby.vu.edu.au:4433/10.1037/1072-5245.10.1.51

Winefield, A. H., \& Jarrett, R. (2001). Occupational stress in university staff. International Journal of Stress Management, 8(4), 285-298. https://doiorg.wallaby.vu.edu.au:4433/10.1023/A:1017513615819 